\title{
1. Introduction. The social and legal context
}

\section{FOREIGN INVESTMENTS AND ENVIRONMENTAL EXPLOITATION}

On a weekly basis, international news reports cases of local populations struggling against the activities of foreign companies that are reputed to endanger both the health and environment of local populations. ${ }^{1}$ For many years, ecologists, politicians and economists have been highlighting the harmful spillovers of foreign direct investments, both in terms of pollution and the over-exploitation of natural resources, in particular when they are located in developing countries. Warnings have also underlined the contribution of such overspills to major global concerns, such as climate change and loss of biodiversity as well as sea and

1 In Chile, for instance, a struggle of farmers against a Spanish electricity company has arisen because the foreign investors have been exploiting a reservoir and extracting water for irrigation purposes (see Le Monde, 23 May 2012). The Peruvian movement in Celendín, meanwhile, is acting against a foreign enterprise which is exploiting a mine and creating risks for the environment and existing water supplies (see Le Monde, 12 July 2012). The Amazonian populations of Ecuador have reacted strongly against Texaco projects in their territories. Oil extraction activities have meant the destruction of parts of high-biodiversity forests and highly polluting spillovers over the land and rivers, while recent armed attacks against activists and lawyers, demanding extraction interruptions and claiming damages, have led to a dangerous escalation in social turmoil (cf. Chapter 5, note 17). While Latin America is a hotspot for such social movements, these examples are multiplying around the world, as attested to by the case of the People's Republic of China, the largest destination for foreign investments worldwide. Since the opening of its markets China has been increasingly exposed to serious pollution, while at the same time greatly contributing to global environmental concerns, mainly through emissions of ozone-depleting substances and greenhouse gases (see Y. Zhao, 'Foreign Direct Investment and Environmental Protection: a Review of the Legal Regime in China', in Yearbook of International Environmental Law (YbIEL) 2006, 213-236). 
atmospheric pollution. Negative spillovers arising from the activities of transnational corporations are part of the broader theme of the undesirable effects of globalization.

Arguably, global and local environmental concerns are due not only to the consequences of foreign investments, but also to various actors belonging to a host state (not only national enterprises, state-owned companies, but also families and consumers). Nevertheless, the reach of foreign investments is growing rapidly worldwide, ${ }^{2}$ and in many developing countries - where major environmental resources are concentrated - these investments represent the bulk of large-size economic activities. ${ }^{3}$ Moreover, the notion of foreign investment itself has assumed a far-reaching scope, according to prevalent legal rules on both the national and international level. ${ }^{4}$

With this in mind, some remarks are due here on the positive social consequences of foreign investments. The huge growth of foreign direct investments over the last two decades, above all by means of the delocalization of manufacturing factories and the related increase of international trade, has contributed to the development of many states and enhanced the living standards of their populations. This aspect should be taken into account when globalization and foreign investments are considered critically from the point of view of sustainable development.

Moreover, foreign direct investments (FDIs) may play a positive function for environmental protection in developing countries, mainly in terms of the transfer of safe and green technologies. Both national ${ }^{5}$ and international ${ }^{6}$

2 Cf. the 2012 World Investment Report provided by the UNCTAD.

3 The massive increase in foreign direct investments (FDIs) is demonstrated by the recent growing phenomenon of South-South investments. By now, emerging countries such as China or Brazil play the double role of host and investor state.

4 Cf. Chapter 3.3 below. It is also worth noting that, by the same token, simple financial instruments, i.e. tools that facilitate capital transfer, may be seen as antagonistic to environmental protection: cf. Benjamin J. Richardson, Financing Sustainability: The New Transnational Governance of Socially Responsible Investment, in YbIEL, vol. 17, 2006, 73-110 ('law makers typically only connect environmental problems directly to companies that extract, consume and pollute. Yet, corporate financiers should be seen as the economy's "unseen polluters", as they finance activities habitually attributed solely to their borrowers and investees', at 75).

5 For instance, in 2010, China adopted a law encouraging foreign investments in new energy, energy-saving and environmental protection industries, among others (UNCTAD, World Investment Report 2010, at 78).

6 United Nations documents on sustainable development underline the importance of FDIs in developing countries: cf. the report Agenda 21 adopted at 
legal instruments often encourage and promote this practice, thereby enhancing a mutually supportive relationship between foreign investments and the environment according to the principle of sustainable development. ${ }^{7}$

In sum, these last remarks underscore the importance of a balanced and mutually supportive relationship between foreign investments and environmental protection. The principle of sustainable development is oriented in this direction. ${ }^{8}$ Nevertheless, in reality the current relationship between foreign investments and the environment is not in equilibrium, as the true benefits of FDIs for environmental protection are somewhat unclear, while the issue of their negative spillovers for human populations and ecosystems remains highly topical at a local and global level.

\section{ENVIRONMENTAL PROTECTION AND 'THE RACE TO THE BOTTOM': DIFFERENT LAYERS OF RULES}

In the past two decades, the national and international literature of the law has become accustomed to the phenomenon known as 'race to the bottom', whereby national environmental law is a competitive factor between states in the race to attract foreign investments to their territories and sell their products abroad. ${ }^{9}$ Enterprises are incentivized, through

the UN Conference on Environment and Development held in Rio de Janeiro in 1992, (1992) 31 ILM, at para. 2.23; the Plan of Implementation of the World Summit on Sustainable Development, U.N. Doc. A/Conf.199/20 (2002), in particular at para. 84 .

7 See A. Newcombe, 'Sustainable Development and International Treaty Law', (2007) Journal of World Investment and Trade, 357-407. For an autonomous role of mutual supportiveness as a legal principle, cf. L. Boisson de Chazournes and M. Moise Mbengue, 'A "Footnote as a Principle". Mutual Supportiveness and its Relevance in an Era of Fragmentation', in H. P. Hestermeyer et al. (eds.), Coexistence, Cooperation and Solidarity. Liber Amicorum Rudiger Wolfrum, vol. II (Leiden, Boston 2012), 1615-1637. See also R. Pavoni, 'Mutual Supportiveness as a Principle of Interpretation and Law Making: a Watershed for the "WTO-andCompeting-Regimes" Debate?' (2010) EJIL, 649-679.

8 The legal nature and scope of sustainable development is highly debated. According to Principle 4 of the 1992 Rio Declaration on Environment and Development: 'In order to achieve sustainable development, environmental protection shall constitute an integral part of the development process and cannot be considered in isolation from it.' To conceive it as a legal principle would better allow for an effective integration of environmental issues throughout the different domains of international law.

9 Cf. for instance, D. C. Esty and D. Geradin, 'Environmental Protection and International Competitiveness. A Conceptual Framework' (1998) Journal of 
relaxed national rules, to move or establish production sectors abroad with the aim of reducing, inter alia, the costs involved in protecting the environment. ${ }^{10}$ Although economists have expressed their doubts about the actual influence of less stringent environmental legislation in terms of attracting foreign investments, ${ }^{11}$ the concrete practice of developing states endorses such concerns. ${ }^{12}$

On the other hand, international law has a limited influence in several areas of concern, and specifically when the threatened commons are situated within the territory of only one state, in deference to the traditional principle of domestic jurisdiction. By the same token, even when multilateral treaties focus on global environmental concerns, their actual influence on the behaviour of states is minimal in all those cases where the objects of regulation are the natural resources situated exclusively in the territory of a single country. ${ }^{13}$ As a consequence, local fears about pollution and nature degradation - which chiefly spark people's reactions against foreign investment - are in practice rarely dealt with at an international level, and the only legal option for the affected populations and their concerns are country tribunals, or where available and only to a certain extent, international human rights mechanisms.

In sum, international environmental law provides important but still limited instruments which are applicable to negative spillovers arising

World Trade, 5-46; B. Chen, 'Globalization and its Losers' (2000) Minnesota Journal of Global Trade, 157-218.

10 This policy is opposed to the economic approach of integrating environmental costs, which is at the core of sustainable development and effectuated by the polluter-pays principle (cf. Principle 16 of the 1992 Rio Declaration on Environment and Development: 'National authorities should endeavour to promote the internalization of environmental costs and the use of economic instruments, taking into account the approach that the polluter should, in principle, bear the cost of pollution, with due regard to the public interest and without distorting international trade and investment').

11 Cf. P. Birnie and A. Boyle, International Law and the Environment, 2nd edition (Oxford 2002), 725.

12 For an overview of economic theories regarding 'pollution heavens', see M. A. Cole, 'Examining the Environmental Case Against Free Trade' (1999) 33 JWT 5, 183-196.

13 The normative force of the Convention on Biological Diversity, for instance, is reduced simply because the protection of biodiversity usually involves defensive actions to protect habitats or ecosystems which are placed under the exclusive sovereignty of only one state. Accordingly states have been reluctant to set out specific and binding obligations in this sense and ultimately 'the Convention has the character of a framework convention' (P. Sands and J. Peel, Principles of International Environmental Law (Cambridge 2012), 461). 
from economic activities situated within the jurisdiction of a single state, and the major role of protecting and conserving the environment remains in the hands of the legislation of states that host such activities. States are sovereign in limiting, by means of their law, the deterioration of their own human habitats and ecosystems, whether they yield or not to the siren call of foreign investment by relaxing legislation. States have a considerable amount of discretion even in coping with global concerns, since international law sets forth obligations only for certain matters, ${ }^{14}$ the enforcement of which is still limited.

The exercise of sovereign prerogatives and regulations for the protection of the environment is summarized in Principle 2 of the Rio Declaration, which was signed at the end of the UN Conference on Environment and Development held in 1992:15

States have, in accordance with the Charter of the United Nations and the principles of international law, the sovereign right to exploit their own resources pursuant to their own environmental and development policies, and the responsibility to ensure that activities within their jurisdiction or control do not cause damage to the environment of other States or of areas beyond the limits of national jurisdiction.

The statement first reaffirms the state's right to permanent sovereignty over its own natural resources, which had already been set forth by the UN General Assembly in the $1960 \mathrm{~s} ;{ }^{16}$ and second outlines the key normative scope of environmental protection in international law. Both these elements are by now commonly accepted to be part of customary international law. ${ }^{17}$

14 International obligations to protect the environment are, however, very important, in particular those dealing with transboundary concerns and shared resources (sea, atmosphere, international rivers, Antarctica etc.), with regard to which a preventive approach is by now commonly accepted (see also note 16). Moreover, even when international legal instruments simply provide for legal purposes or soft law rules, they are important in influencing the behaviour of and cooperation between states and may prove crucial in connection with other international legal regimes, such as international investment law. See below, Part II, Chapter 7.

15 It has almost literally reaffirmed Principle 21 of the Stockholm Declaration of 1972 .

16 See in particular the UNGA Res. No. 1803 of 14 December 1962.

17 The UNGA Resolution quoted above provides the best evidence in support of the customary nature of the sovereign states' right to exploit their own natural resources. As to the second element of Principle 2, the ICJ Advisory Opinion on Nuclear Weapons of 1996 makes an authoritative statement: 'The existence of the 
The idea of a 'race to the bottom' clearly explains how national environmental legislation may be influenced by economic factors, and the concept of sustainable development itself implies a balance between environmental, social and economic elements. This means that while environmental law, at both the national and international levels, is the natural instrument by which to address local and global concerns about pollution and the deterioration of natural resources, another kind of law plays a key role in this process, that is, the rules and principles that variously promote the liberalization of economic relations and activities.

Liberalizing goals may hold a state back from developing or improving its environmental legislation, and when such goals underlie binding rules, those rules may conflict with environmental regulation. In cases where conflicts are simply internal to a national legal system, the rules relating to applicable law and constitutional norms will provide the legal techniques to find solutions. However, this question becomes more complicated when international law, and in particular international economic law, is involved. In most cases, conflicts ensue from a clash between international rules that protect commercial interests and national legislation that provides for environmental measures. Major concerns over the limitations to sovereign powers in the pursuit of key public purposes such as environmental and human health protection concentrate primarily on the consequences of international investment law and arbitration. ${ }^{18}$

general obligation of states to ensure that activities within their jurisdiction and control respect the environment of other states or of areas beyond national control is now part of the corpus of international law relating to the environment' ('Legality of the Threat or Use of Nuclear Weapons, Advisory Opinion' (1996) ICJ Reports, para. 29). For references to other international practices supporting the customary nature of transboundary state responsibility, see P. Sands, Principles of International Environmental Law (Cambridge 2003), 241-246. Scholars tend to strictly link such 'responsibility to not cause damage' and the consequent obligation to compensate harm with the obligation to prevent damage to the environment: cf. Sands, ibid., at 246-247; Birnie and Boyle, supra note 11, at 111-114.

18 For many years, such concerns focused predominantly on WTO law. Today these fears have somewhat faded - principally due to key decisions in favour of the environment (see below Chapter 6, 3.A) - and mainly regard specific features, e.g. the role of the precautionary principle and the regulation of situations of scientific uncertainty in a given context. 